\title{
Unravelling the potentialities of tocilizumab for the development of a potential immunotherapeutic regimen against COVID-19_A narrative review
}

\author{
Manish Dhawan ${ }^{1,2}$, Kuldeep Dhama ${ }^{3}$, Manisha Parmar ${ }^{4}$, Alisha Sharma ${ }^{5}$, Steffy Angural ${ }^{6 *}$ \\ ${ }^{1}$ Department of Microbiology, Punjab Agricultural University, Ludhiana, India. \\ ${ }^{2}$ The Trafford Group of Colleges, Manchester, UK. \\ ${ }^{3}$ Division of Pathology, ICAR-Indian Veterinary Research Institute, Bareilly, India. \\ ${ }^{4}$ Department of Veterinary Microbiology, Guru Angad Dev Veterinary and Animal Sciences University, Ludhiana, India. \\ ${ }^{5}$ Institute of Microbiology, Leibiniz University, Hannover, Germany. \\ ${ }^{6}$ Department of Medical Lab Technology, Faculty of Applied Health Sciences, GNA University, Phagwara, India.
}

\section{ARTICLE INFO \\ Received on: 20/05/2021 \\ Accepted on: 23/07/2021 \\ Available Online: 03/11/2021}

\section{Key words:}

Cytokine storm, COVID-19, hyperinflammation, interleukin-6 (IL-6), tocilizumab (TCZ), SARSCoV-2.

\begin{abstract}
The severity of COVID-19 (coronavirus disease 2019) disease caused by severe acute respiratory syndrome coronavirus-2 (SARS-CoV-2) has been associated with hyperinflammation induced by excessive release of a range of cytokines and chemokines. Among a plethora of cytokines, interleukin-6 (IL-6) plays a pivotal role in the immunopathology of SARS-CoV-2 infection as IL-6 has been proposed to initiate hypersecretion of cytokines by activating the Janus kinases-signal transducer and activator of transcription (JAK-STAT) pathway. Hence, targeting IL-6 and its receptor can be an appropriate therapeutic strategy to treat SARS-CoV-2 infection. However, tocilizumab (TCZ) is a well-known monoclonal antibody for its anti-inflammatory activities. TCZ has been designed to bind two different IL-6 receptors, viz., membrane-bound and soluble receptors. As an antagonist of IL-6 receptors, TCZ inhibits the JAK-STAT signaling pathway, which is essential for the transcriptional activation of cytokines-producing genes. Hence, the inhibition of IL-6 receptors can substantially reduce hyperinflammation, a key characteristic of severely infected patients with SARS-CoV-2 infection. TCZ has much promise in terms of treating SARS-CoV-2-related hyperinflammation, acute respiratory distress syndrome, and multiple organ damage. Hence, TCZ has been proposed as a potential therapeutic drug for treating COVID-19 disease. However, several discrepancies still exist, such as a well-defined molecular mechanism, efficacy, and safety parameters. In this context, various databases, including Medline, ResearchGate, PubMed, Science Direct, Scopus, and Google Scholar, were explored employing keywords such as "Cytokine storm", "COVID-19", "hyper inflammation", "IL-6", "TCZ", and "SARS-COV-2" up to May 2021. The authors independently collected and evaluated research papers for inclusion in the current review, relying on their relatedness to the main theme of the literature review. So, this narrative review aims to provide updated information about the molecular mechanism, efficacy, and safety of TCZ in the treatment of COVID-19. However, several contradictions and challenges associated with TCZ use in the treatment of severely infected patients with COVID-19 have also been discussed.
\end{abstract}

*Corresponding Author

Steffy Angural, Department of Medical Lab Technology, Faculty of Applied

Health Sciences, GNA University, Phagwara, India.

E-mail: steffy@gnauniversity.edu.in 


\section{INTRODUCTION}

As of May 2021, the COVID-19 (coronavirus disease 2019) pandemic, which was caused by a novel form of beta coronavirus known as "severe acute respiratory syndrome coronavirus-2" (SARS-CoV-2), had spread to all corners of the globe, eventually caused more than 3 million deaths (Dhama et al., 2020a; WHO, 2021). This condition has caused widespread panic, global risks, financial setbacks, and a steady increase in COVID-19 cases regularly. The world is having severe trouble combating this pandemic due to a shortage of successful drug candidates of choice, though a few vaccinations have recently been developed, and global vaccination is underway to combat COVID-19 (Dhama et al., 2020b; Dhawan et al., 2020; Malik et al., 2020; Singh and Gupta., 2021).

COVID-19 is a novel evolving infectious disease with complex pathogenesis characterized by the spontaneous and hypersecretion of pro-inflammatory cytokines and impaired immune response, resulting in the cytokine storm or cytokine release syndrome (CRS) (Moore and June, 2020). Several reports have suggested that the hypersecretion of cytokines or CRS is a crucial pathogenic factor (Rabaan et al., 2021a, 2021b), and the uncontrolled secretion of proinflammatory and inflammatory cytokines have been linked with the intensity of virus infection and fatality rates. However, the secretion of pro-inflammatory cytokines such as tumour necrosis factor-alpha (TNF-alpha), interleukin-1 (IL-1), and interleukin-6 (IL-6) has been considered crucial, which causes a hyperinflammatory reaction in the lung alveolar cells by recruiting macrophages, T cells, and B cells. Furthermore, immune cells such as macrophages have been hypothesized to recruit many inflammatory monocytes into alveolar cells, allowing for the release of massive quantities of cytokines in the alveoli, resulting in hypersecretion of cytokines in severely infected patients with SARS-CoV-2 infection. Moreover, this hyperinflammatory response leads to multiple organ failure, acute respiratory distress syndrome (ARDS), or pneumonia that may result from this chain of events (Pelaia et al., 2021; Rabaan et al., 2021a, 2021b).

Innate immune response, also known as the first line of defense, provides a significant role in protecting against the SARS-CoV-2 infection. As in young people, a well-functioning innate immune system is imperative to eliminate the viral infection. Nonetheless, any disruption in a normally functioning immune response, whether exaggerated in terms of excessive cytokine release or caused by defects in the patient's immune response, such as disruption in interferon-I (IFN-I) type immunity, appears to be detrimental and can be life-threatening (Andersen et al., 2020). Hyperactivation of the immune system, through the production of pro-inflammatory cytokines like IL-6, may be a crucial factor in the pathophysiology of COVID-19-related serious illness (Del Valle et al., 2020), and IL-6 is a pleiotropic pro-inflammatory cytokine formed by lymphocytes, monocytes, and fibroblasts. The SARS-CoV-2 infection causes bronchial epithelial cells to produce IL-6 in a dose-dependent manner. Recently, among a plethora of cytokines, IL-6 has been reported as the most critical pro-inflammatory cytokine engaged in cytokine storm or hyperinflammation, and it has also been identified to become a poor prognostic factor in the COVID-19 disease (ElShabrawy et al., 2021; Wei et al., 2021; Zhou et al., 2020).
The corticosteroid, such as dexamethasone, is one of the few treatments that has been used to treat hyperinflammation and is reported to decrease the mortality in hospitalized patients with COVID-19 (Horby et al., 2021; Sharun et al., 2020). However, there has been much curiosity in seeing whether using additional, more selective anti-inflammatory agents in addition to steroids could help in the treatment of COVID-19 (Kow and Hasan, 2021; Sharun et al., 2020). Recent research concluded that using tocilizumab (TCZ) in addition to dexamethasone is a cost-effective immunosuppressive and immunomodulatory intervention for the treatment of critically ill patients with SARS-CoV-2 infection (Sinha and Linas, 2021). In this context, various immunomodulatory and anti-inflammatory agents such as anakinra, sarilumab, siltuximab, and TCZ have been suggested for the treatment of COVID-19 (Khan et al., 2021; Meira et al., 2021; Verma et al., 2021). Among a range of immunomodulatory and immunosuppressive agents, anti-IL-6R agents have been proposed as a promising therapeutic regimen to cure COVID-19 as they contain the potential to reduce the hyperinflammatory response in the lung alveolar cells (Li et al., 2021; Rubin et al., 2021; Zhang et al., 2020; Zhao, 2020). TCZ, a humanized monoclonal antibody (MAB) that can target both membrane-bound and soluble forms of the IL-6 receptor, has been considered as a potential therapeutic drug counter-effect the cytokine storm. A growing number of studies have evaluated its efficacy in treating severe COVID-19 (Cortegiani et al., 2021; Meira et al., 2021; Pelaia et al., 2021; Richier et al., 2021).

TCZ has attracted the interest of many study groups among a plethora of signaling inhibitors and receptor antagonists that have been assessed for their immunomodulatory ability to regulate the hyperinflammatory response (Bhattacharjee et al., 2021; Iqbal Yatoo et al., 2021; Izda et al., 2021). TCZ, a recombinant $\mathrm{MAB}$ that inhibits both soluble and membranebound IL-6 receptors, is typically used to manage patients with rheumatoid arthritis and paediatric patients with chronic arthritis. However, its efficacy has recently been shown in other severe immune disorders and inflammatory diseases, including giant cell arteritis (Villiger et al., 2016), multicentric Castleman's disease (Galeotti et al., 2012), and, most notably, for treating CRS in chimeric antigen receptor T-cell cancer therapy (Le et al., 2018). However, no clear findings were seen in these studies connecting TCZ to COVID-19 treatment. As a result, this narrative analysis aims to provide updated information on the effectiveness of TCZ in the treatment of COVID-19.

\section{METHODOLOGY OF LITERATURE REVIEW}

In order to obtain an updated insight into the therapeutic potential of TCZ against COVID-19, a comprehensive review of the literature was performed. Authentic scholarly databases such as ScienceDirect, MEDLINE, PubMed, ResearchGate, and Google Scholar were searched for relevant research articles using keywords such as TCZ, SARS-CoV-2, COVID-19, IL-6, and cytokine storm. Until the May 18, 2021, research papers were screened and chosen collectively by authors based on inclusion and exclusion criteria such as relevance to the current study. Following a literature review, the information was thoroughly reviewed, and only closely matched experiments were chosen for critical discussion, with unrelated or generalized studies being 
excluded. The research papers' names and abstracts were screened first, and unrelated findings were eliminated. In addition, complete academic papers were chosen for their contribution to the current study. Finally, 79 articles were chosen to apply to the current research, and the review article was written.

\section{The involvement of cytokine storm and IL-6 in prognosis of COVID-19}

The release of numerous cytokines is vividly associated with the emergence of multiple clinical manifestations, such as excessive interferon- $\gamma$ (IFN- $\gamma$ ) secretion, resulting in headaches, chills, dizziness, fatigue, and fever. Like IFN- $\gamma$, TNF- $\alpha$ causes flulike symptoms along with fever, fatigue, and malaise but can also lead to lung damage, vascular leaking, heart failure, and synthesis of acute-phase protein (Shimabukuro-Vornhagen et al., 2018). The secretion of IL-6 causes vascular leak syndrome, triggering coagulation, and complement pathways leading to the prominent indications of CRS, i.e., blockage of small blood vessels (Hunter and Jones, 2015; Tanaka et al., 2016). It is important to note that IL-6 is related to induce cardiomyopathies by stimulating coronary artery disease and myocardial dysfunction (Pathan et al., 2004). Moreover, severe CRS may also occur due to the activation of endothelial cells (Shimabukuro-Vornhagen et al., 2018), and endothelial dysfunction can result in hypotension, capillary leakage, and impaired blood clotting.

Various clinical studies have established the substantial role of IL-6 in eliciting the immune response. Moreover, there is a strong interconnection of IL-6 in the progression of infection and in the development of IL-6, which has been attributed to the higher fatality rates associated with various pathological conditions, including coronaviruses (CoVs) infections (Fehr et al., 2017). A substantial increase in IL-6 concentration has been identified during certain pathological conditions, including viral infections only as compared to normal conditions, which contributes to the release of many other cytokines by triggering two forms of signalling pathways, namely classical and trans signalling pathways. However, in the classical pathway, IL-6 binds to a membrane-bound receptor on the surface of immune cells such as natural killer (NK) cells, macrophages, B and T cells. The binding of IL-6 leads to a complex formation that binds with transducer molecules which in turn transduce the signaling pathway through the Janus kinases-signal transducer and activator of transcription (JAK-STAT) pathway (Braun et al., 2016) (Fig. 1). This leads to the activation of several types of inflammatory effects in a range of immune cells, such as macrophages and NK cells, which are important constituents of innate immune response and play a significant role in the generation of the adaptive immune system (Kang et al., 2019). Besides, IL-6 can induce a strong proinflammatory response, possibly in every type of cell present in our system, by trans-signalling pathway. It is important to consider that some reports have shown the secretion of IL- 6 by all kinds of immune and stromal cells (Jones and Jenkins, 2018).

Several research groups have recently proposed that the severity of COVID-19 disease and fatality rates in hospitalized patients are linked with hypersecretion of a variety of cytokines and chemokines, resulting in CRS or cytokine storm (Rabaan et al., 2021a, 2021b; Xu et al., 2020a). This cytokine storm appears to be linked to the progression of the infection from moderate to critical. Cytokines are small chemical messengers that can activate both the adaptive and innate immune systems. INFs, ILs, growth factors, TNFs, and chemokines are examples of small molecules (Tisoncik et al., 2012). Surprisingly, the connection between CRS or cytokine storm and high morbidity has been reported in previous viral infections caused by other CoVs, such as SARSCoV and MERS-CoV (Channappanavar and Perlman, 2017).

In addition, various pro-inflammatory factors, such as interleukins (IL)-2, 6, 8, 10, 1-beta, TNFs, IFNs, and colonystimulating factors (GM-CSF), have recently been implicated in the progression of cytokine storm in a number of reports (ElShabrawy et al., 2021; Jesenak et al., 2020; Rabaan et al., 2021a). Furthermore, cytokine storm has been attributed to the causative factor behind multiple organ damage and fatalities during SARSCoV-2 infection (Salahshoori et al., 2021). Recently, Peng et al. 2021 also proposed that the cytokine storm plays a pivotal role in the progression of SARS-CoV-2 infection, and it might be a significant cause of ARDS and multiple organ dysfunction, and higher mortality rates in immunocompromised patients (Peng et al., 2021).

However, IL-6 has been proposed as a key factor in determining the severity of SARS-CoV infection among a variety of proinflammatory cytokines. It is important to keep in mind that IL-6 signalling is critical in causing this cytokine storm in COVID patients with severe symptoms. Some molecules should be available or added to inhibit both of this interleukin's signalling pathways in order to monitor or regulate the lethal consequences of this individual IL. TCZ, a humanized MAB primarily engineered to target IL-6 receptors and minimize the detrimental effects of SARS-CoV infection, is one of these molecules that can serve as an appropriate antagonist of IL-6 signalling (Fig. 1). The following section will discuss the clinical studies indicating the therapeutic potential of TCZ to treat COVID-19.

\section{Therapeutic potential of TCZ in the treatment of COVID-19}

Antibodies against IL-6 suppress the classical cis- and trans-signaling pathway. However, the IL- 6 trans-presentation does not affect by the antagonists of IL-6. In this context, antagonists of IL-6 receptors such as TCZ and sarilumab have been reported to effectively suppress all these three modes of IL-6 signalling (Garbers et al., 2018). In comparison to IL-6 inhibitors, antagonists of IL-6 receptors have been considered as safe and effective means to control the hyperinflammatory response efficiently (Chen et al., 2021). TCZ, a well-known recombinant humanized MAB, prevents IL-6 binding and widely used in autoimmune diseases such as rheumatoid arthritis. TCZ inhibits all three modes of IL-6 signalling by interfering with the epitope of IL-6R (Heink et al., 2017; Tanaka et al., 2012; Zhang et al., 2020).

Many research groups and medical practitioners are interested in investigating the potential of TCZ in treating COVID-19 as an effective IL-6 receptor antagonist, based on recent reports of a strong association between elevated IL-6 levels and fatality rates in severely ill patients with COVID-19 (Dastan et al., 2020; Gu et al., 2021; Hermine et al., 2021; O'Leary, 2021). In this context, a recent study on critically ill patients with COVID-19 who are hospitalized, TCZ has been reported to increase oxygenation and reduce inflammatory biomarkers (Price et al., 2020; Xu et al., 2020b). Although TCZ therapy has still 


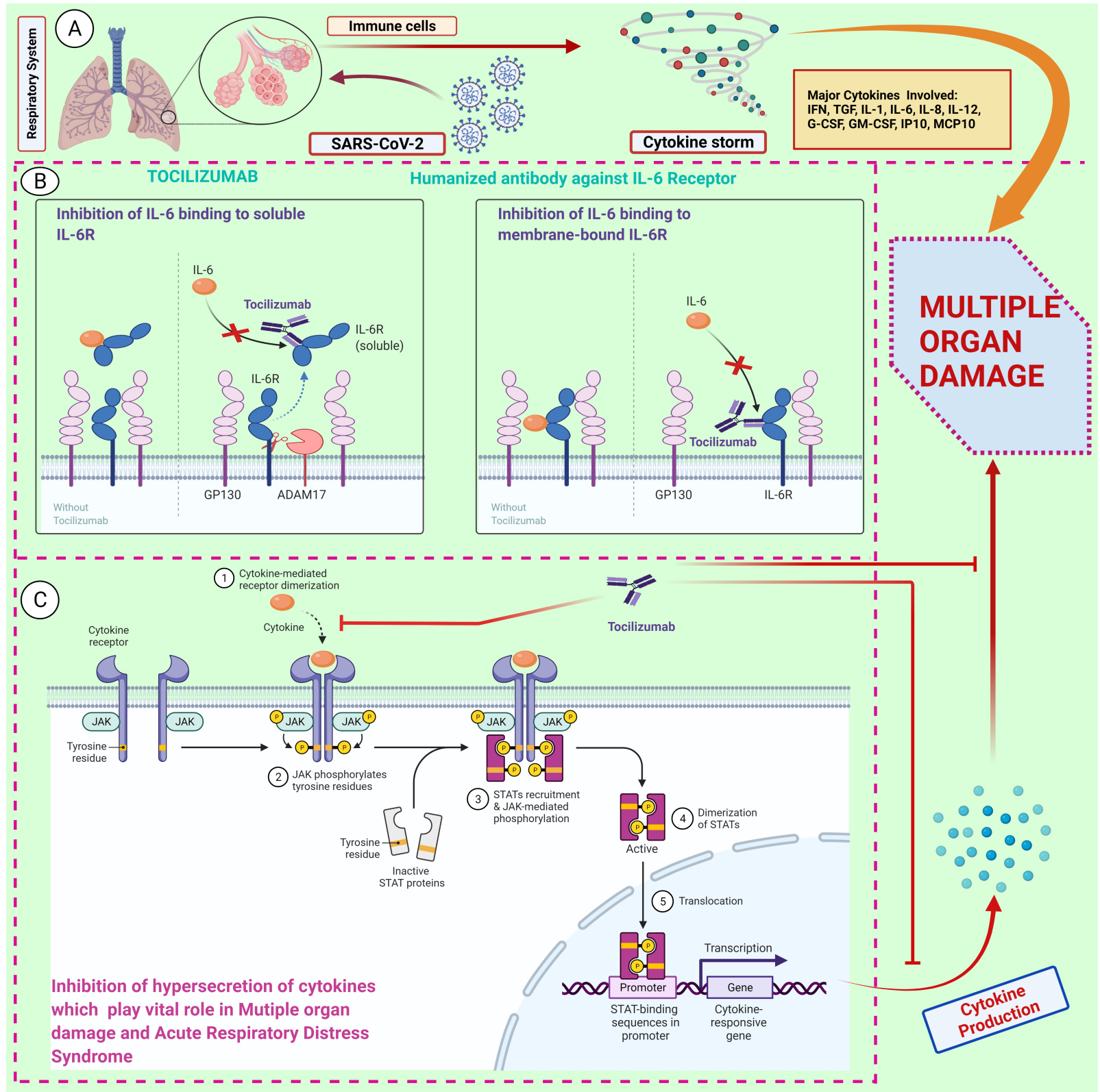

Figure 1. A schematic representation of the action mechanism of tocilizumab in repressing the hyperinflammatory response. A) SARS-CoV-2induced cytokine storm by activation of various immune cells through pro-inflammatory cytokines and chemokines, specifically IL-6. B) IL-6 can either interact with membrane-bound IL-6R or bind to soluble IL-6R, which in turn lead to the activation of classic cis-signaling and transsignaling, respectively. C) Possible mechanism of tocilizumab in inhibiting the IL-6 receptor and repressing the JAK-STAT pathway. This, in turn, reduces the hyperinflammatory response. Abbreviations: SARS-CoV-2, severe acute respiratory syndrome coronavirus 2; IL-6, interleukin-6; IL-6R, IL-6 receptor; JAK, Janus kinase; STAT, signal transducer and activator of transcription. The figure was created with BioRender.com. (https://biorender.com/, accessed on 12 May 2021)

not been linked to pathogenesis, it has been linked to a reduction in COVID-19-associated lymphopenia (Giamarellos-Bourboulis et al., 2020). Furthermore, a recently published meta-analysis of existing clinical trials using TCZ showed that COVID-19 patients treated with TCZ had a $12 \%$ lower mortality rate than the control group (Malgie et al., 2020). In the latest report, TCZ therapy was linked to significant clinical progress and long-term survival in COVID-19-positive chronically ill patients (Toniati et al., 2020). Patients who were given TCZ, on the other hand, had higher levels of two important biomarkers, $\mathrm{C}$-reactive protein (CRP) and
IL-6, which signify the onset of a cytokine storm. Furthermore, they claimed that TCZ had a short-term survival advantage (Ramaswamy et al., 2020).

However, as per another large clinical trial's recent massive analysis, incorporating IL-6 receptor antagonists such as TCZ and sarilumab improved outcomes by reducing mortality in critically ill patients with COVID-19 and increasing organ support in intensive care units (ICUs) (Gordon et al., 2021). In COVID-19 patients hospitalized with hypoxia and systemic inflammation, TCZ increased survival rates and other health 
effects. Both benefits were shown regardless of the degree of respiratory aid and were significantly comparable to the benefits of systemic corticosteroids (Horby et al., 2021). Furthermore, a recent clinical trial of 170 patients treated with TCZ found that administering TCZ to critically ill patients with COVID-19 reduces mortality and accelerates clinical improvement. Moreover, increased oxygenation has been reported, which reduces the oxygen dependency in critically ill patients with COVID-19 (Flisiak et al., 2021). Surprisingly, a growing body of evidence suggested suggests that the requirement for mechanical ventilation and administration to the ICU have been reduced in the patients treated with TCZ (Flisiak et al., 2021; Hermine et al., 2021; Rezaei et al., 2021; Tleyjeh et al., 2021). TCZ enhanced recovery and other clinical outcomes in hospitalized COVID-19 patients with oxygen deprivation and systemic inflammation, according to a new randomized, controlled, open-label platform study. Both advantages were shown independent of the level of respiratory assistance and were in comparison to the systemic corticosteroids' advantages (RECOVERY Collaborative Group, 2021). Another recent meta-analysis showed that TCZ decreases the risk of mechanical ventilation in hospitalized patients with COVID-19. It has been suggested that TCZ decreases the risk of poor prognosis of the SARS-CoV-2 infection and secondary infections in hospitalized patients with COVID-19 (Tleyjeh et al., 2021). Recently, a clinical trial evaluated the timing and efficacy of TCZ treatment in patients with SARS-CoV-2 infection and increased concentration of IL-6. It was confirmed that the use of $\mathrm{TCZ}$ at the early stages of the viral infection and cytokine storm (IL-6 level $100 \mathrm{pg} / \mathrm{ml}$ ) could effectively improve the clinical outcomes in patients by blocking the IL-6 signalling pathway ( $\mathrm{Li}$ et al., 2021).

\section{Contradictions on the efficacy and safety of TCZ}

In contrast, in a randomized, double-blind placebocontrolled trial in hospitalized patients with severe SARSCoV-2 infection, TCZ therapy was shown to be non-significant in reducing mortality. Furthermore, it was confirmed that the use of TCZ had little effect on oxygen requirements or clinical improvement (Stone et al., 2020). According to a recent literature review of several clinical trials, including the use of TCZ to treat COVID-19, there is an inadequate evidence on the effectiveness and safety of TCZ. As a result, the therapeutic use of TCZ should be reviewed and subsequently revised (Cortegiani et al., 2021; Kow and Hassan, 2021).

Recently, it has been found that the use of TCZ reduced the requirement of mechanical ventilation and risks of death after 14 days but did not improve the mortality rates during day 28 in hospitalized patients with COVID-19 (Hermine et al., 2021). Further, a retrospective analysis constituting 77 COVID-19 patients found the TCZ therapy improved oxygenation in patients with COVID-19 during early days, but the survival rate was not changed with the use of TCZ (Okoh et al., 2021). In another retrospective analysis, patients with hyperinflammation did not report any significant clinical improvements compared to the standard therapeutic regimen after 28 days of treatment (Campochiaro et al., 2020).

Furthermore, current research suggests that TCZ has a positive impact on patients with more intense COVID-19 symptoms, which reduces the need for intensive mechanical ventilation, lowering both mortalities and enhancing therapeutic efficacy, while patients with less severe disease are unlikely to benefit. It is indeed possible that perhaps the advantage of inhibition of IL-6R is connected to the peak of the inflammatory response and manifests itself as clinical worsening (Angriman et al., 2021). There is no doubt that the clinical trials offer the most conclusive data till date to resolve the debate about whether TCZ should be added to the existing therapeutic strategy for COVID-19 patients who are seriously ill (Al-Qaaneh and Al-Ghamdi, 2021). Indeed, that seems to be appropriate. However, TCZ's effectiveness and safety in other conditions, including patients with CRP concentrations less than $75 \mathrm{mg} / 1$ and paediatric patients, are still unknown. In addition, due to some negative evidence regarding the utilisation of TCZ in hospitalised patients with COVID-19, it is difficult to conclude that TCZ will be beneficial in all patients with SARS-CoV-2 infection (Mombrun and Valette, 2021). Moreover, these contradictions necessitate the development of new therapies to help decrease mortality in critically ill COVID-19 patients (Al-Qaaneh and Al-Ghamdi, 2021). Several therapies are being researched, including other immunomodulators and antibodies against the SARS-CoV-2 spike antigen (Gupta and Leaf, 2021; Wang et al., 2021), which can minimize mortality rates and the need for mechanical ventilation in patients. In addition, there are still several question marks and contradictions raised by Angriman et al. 2021 such as:

- What is the best time to start using MABs such as TCZ that target both soluble and membrane-bound receptors?

- What are the attributes of patients which can be treated with TCZ? Are these only severely infected patients with COVID-19?

- What is the efficacy and risk status of TCZ in patients at risk of other deadly infections, including bacterial and fungal, and viral infections?

- Will TCZ be used to treat COVID-19 patients at a reasonable cost?

\section{CONCLUSIONS AND FUTURE PROSPECTS}

Several studies have concluded that IL-6 is a crucial factor in the generation of hyperinflammatory response or cytokine storm. The cytokine storm plays a crucial role in the immunopathology of SARS-CoV-2 infection. Hypersecretion of cytokines leads to multiple organ failure, ARDS, and systemic injuries. As a result, exploitation of treatment modalities such as targeting IL-6 receptors can be proven as efficient and reliable strategies for treating COVID-19. Inhibition of IL-6R by TCZ seems to be a very promising strategy for treating critically ill patients with COVID-19. Recently, large and small clinical trials have demonstrated the efficacy and safety of TCZ in treating hospitalized COVID-19 patients. Recent evidences have suggested that the exploitation of TCZ has a beneficial role in treating pulmonary failure and reduces the fatalities rates in hospitalized patients with COVID-19. On the other hand, some contradictory studies reported the insignificant effects of TCZ in improving the clinical outcomes in patients with COVID-19. The contradictions could be correlated with patients' diverse immune responses that vary among the individuals with the severity of hyper-inflammatory response. Moreover, the complex immunopathology involved in 
SARS-CoV-2 infection is still not fully unraveled. Therefore, it can be proposed that the use of TCZ could be very successful in reducing the hyperinflammatory response in critically ill patients with COVID-19. Several contradictions and inconsistencies on the safety and efficacy of the use of TCZ in hospitalized patients with COVID-19 may also include other possible factors such as conditions like the recruitment time of the patients and the time of initiation of treatment. Hence, clinical trials of larger size samples are the utmost need of the present time to establish concrete proofs about the safety and efficacy of TCZ to treat critically ill patients with COVID-19.

\section{ACKNOWLEDGEMENTS}

All the authors acknowledge and thank their respective institutes and Universities.

\section{AUTHOR CONTRIBUTIONS}

All the authors substantially contributed to the conception, compilation of data, checking, and approving the final version of the manuscript, and agreed to be accountable for its contents.

\section{CONFLICT OF INTEREST}

All authors declare that there exist no commercial or financial relationships, that could, in any way, lead to a potential conflict of interest.

\section{FUNDING}

This compilation is a review article written by its authors and requires no substantial funding to be stated.

\section{REFERENCES}

Al-Qaaneh AM, Al-Ghamdi FH. Tocilizumab prescribing criteria for COVID-19 patients. Hum Vaccines Immunother, 2021; 17(4):1128. Andersen KG, Rambaut A, Lipkin WI, Holmes EC, Garry RF. The proximal origin of SARS-CoV-2. Nat Med, 2020; 26(4):450-2.

Angriman F, Ferreyro BL, Burry L, Fan E, Ferguson ND, Husain S, Keshavjee SH, Lupia E, Munshi L, Renzi S, Ubaldo OGV, Rochwerg B, Del Sorbo L. Interleukin-6 receptor blockade in patients with COVID-19: placing clinical trials into context. Lancet Respir Med, 2021; 9(6):655-64.

Bhattacharjee A, Saha M, Halder A, Debnath A, Mukherjee O. Therapeutics and vaccines: strengthening our fight against the global pandemic COVID-19. Curr Microbiol, 2021; 78(2):435-48.

Braun GS, Nagayama Y, Maruta Y, Heymann F, van Roeyen CR, Klinkhammer BM, Boor P, Villa L, Salant DJ, Raffetseder U, Rose-John S, Ostendorf T, Floege J. IL-6 trans-signaling drives murine crescentic GN. J Am Soc Nephrol, 2016; 27(1):132-42.

Campochiaro C, Della-Torre E, Cavalli G, De Luca G, Ripa M, Boffini N, Tomelleri A, Baldissera E, Rovere-Querini P, Ruggeri A, Monti G, De Cobelli F, Zangrillo A, Tresoldi M, Castagna A, Dagna L, TOCI-RAF Study Group. Efficacy and safety of tocilizumab in severe COVID-19 patients: a single-centre retrospective cohort study. Eur J Intern Med, 2020; 76:43-9.

Channappanavar R, Perlman S. Pathogenic human coronavirus infections: causes and consequences of cytokine storm and immunopathology. Semin Immunopathol, 2017; 39(5):529-39.

Chen JJ, Zhang LN, Hou H, Xu L, Ji K. Interleukin-6 signaling blockade treatment for cytokine release syndrome in COVID-19 (Review). Exp Ther Med, 2021; 21(1):24.

Cortegiani A, Ippolito M, Greco M, Granone V, Protti A, Gregoretti C, Giarratano A, Einav S, Cecconi M. Rationale and evidence on the use of tocilizumab in COVID-19: a systematic review. Pulmonology, 2021; 27(1):52-66
Dastan F, Saffaei A, Haseli S, Marjani M, Moniri A, Abtahian Z, Abedini A, Kiani A, Seifi S, Jammati H, Hashemian SMR, Pourabdollah Toutkaboni M, Eslaminejad A, Heshmatnia J, Sadeghi M, Nadji SA, Dastan A, Baghaei P, Varahram M, Yousefian S, Salamzadeh J, Tabarsi P. Promising effects of tocilizumab in COVID-19: a non-controlled, prospective clinical trial. Int Immunopharmacol, 2020; 88:106869.

Del Valle DM, Kim-Schulze S, Huang HH, Beckmann ND, Nirenberg S, Wang B, Lavin Y, Swartz TH, Madduri D, Stock A, Marron TU, Xie H, Patel M, Tuballes K, Van Oekelen O, Rahman A, Kovatch P, Aberg JA, Schadt E, Jagannath S, Mazumdar M, Charney AW, Firpo-Betancourt A, Mendu DR, Jhang J, Reich D, Sigel K, Cordon-Cardo C, Feldmann M, Parekh S, Merad M, Gnjatic S. An inflammatory cytokine signature predicts COVID-19 severity and survival. Nat Med, 2020; 26(10):1636-43.

Dhama K, Khan S, Tiwari R, Sircar S, Bhat S, Malik YS, Singh KP, Chaicumpa W, Bonilla-Aldana DK, Rodriguez-Morales AJ. Coronavirus disease 2019-COVID-19. Clin Microbiol Rev, 2020a; 33(4): e00028-20.

Dhama K, Patel SK, Pathak M, Yatoo MI, Tiwari R, Malik YS, Singh R, Sah R, Rabaan AA, Bonilla-Aldana DK, Rodriguez-Morales AJ. An update on SARS-CoV-2/COVID-19 with particular reference to its clinical pathology, pathogenesis, immunopathology and mitigation strategies. Travel Med Infect Dis, 2020b; 37:101755.

Dhawan M, Angural S, Parmar M. Tuberculosis during the COVID-19: impact, challenges and management. J Exp Biol Agric Sci, 2020; 8(spl-1):79-86.

Dhawan M, Parmar M, Sharun K, Tiwari R, Bilal M, and Dhama K. Medicinal and therapeutic potential of withanolides from Withania somnifera against COVID-19. J Appl Pharm Sci, 2021; 11(04):006-13.

El-Shabrawy M, Alsadik ME, El-Shafei M, Abdelmoaty AA, Alazzouni AS, Esawy MM, \& Shabana, MA. Interleukin-6 and C-reactive protein/albumin ratio as predictors of COVID-19 severity and mortality. Egypt J Bronchol, 2021; 15(1):1-7.

Fehr AR, Channappanavar R, Perlman S. Middle east respiratory syndrome: emergence of a pathogenic human coronavirus. Annu Rev Med, $2017 ; 14 ; 68: 387-99$

Flisiak R, Jaroszewicz J, Rogalska M, Lapinski T, BerkanKawinska A, Bolewska B, Tudrujek-Zdunek M, Kozielewicz D, Rorat M, Leszczynski P, Klos K, Kowalska J, Pabjan P, Piekarska A, Mozer-Lisewska I, Tomasiewicz K, Pawlowska M, Simon K, Polanska J, Zarebska-Michaluk D. Tocilizumab improves the prognosis of COVID-19 in patients with high IL-6. J Clin Med, 2021; 10(8):1583.

Galeotti C, Boucheron A, Guillaume S, Kone-Paut I. Sustained remission of multicentric Castleman disease in children treated with tocilizumab, an anti-interleukin- 6 receptor antibody. Mol Cancer Ther, $2012 ; 11: 1623-6$

Garbers C, Heink S, Korn T, Rose-John S. Interleukin-6: designing specific therapeutics for a complex cytokine. Nat Rev Drug Discov, 2018; 17(6):395-412.

Giamarellos-Bourboulis EJ, Netea MG, Rovina N, Akinosoglou K, Antoniadou A, Antonakos N, Damoraki G, Gkavogianni T, Adami M-E, Katsaounou P, Ntaganou M, Kyriakopoulou M, Dimopoulos G, Koutsodimitropoulos I, Velissaris D, Koufargyris P, Karageorgos A, Katrini K, Lekakis V, Lupse M, Kotsaki A, Renieris G, Theodoulou D, Panou V, Koukaki E, Koulouris N, Gogos C, Koutsoukou A. Complex immune dysregulation in COVID-19 patients with severe respiratory failure. Cell Host Microbe, 2020; 27:992-1000.

Gordon AC, Mouncey PR, Al-Beidh F, Rowan KM, Nichol AD, Arabi YM, Annane D, Beane A, Van Bentum-Puijk W, Berry LR, Bhimani Z, Bonten MJM, Bradbury CA, Brunkhorst FM, Buzgau A, Cheng AC, Detry MA, Duffy EJ, Estcourt LJ, Fitzgerald M, Goossens H, Haniffa R, Higgins AM, Hills TE, Horvat CM, Lamontagne F, Lawler PR, Leavis HL, Linstrum KM, Litton E, Lorenzi E, Marshall JC, Mayr FB, McAuley DF, McGlothlin A, McGuinness SP, McVerry BJ, Montgomery SK, Morpeth SC, Murthy S, Orr K, Parke RL, Parker JC, Patanwala AE, Pettila V, Rademaker E, Santos MS, Saunders CT, Seymour CW, Shankar-Hari M, Sligl WI, Turgeon AF, Turner AM, van de Veerdonk FL, Zarychanski R, Green C, Lewis RJ, Angus 
DC, McArthur CJ, Berry S, Webb SA, Derde LPG. Interleukin-6 receptor antagonists in critically ill patients with Covid-19. N Engl J Med, 2021; 01.

Gu Y, Wang D, Chen C, Lu W, Liu H, Lv T, Song Y, Zhang F. $\mathrm{PaO} 2 / \mathrm{FiO} 2$ and IL-6 are risk factors of mortality for intensive care COVID-19 patients. Sci Rep, 2021; 11(1):1-8.

Gupta S, Leaf DE. Tocilizumab in COVID-19: some clarity amid controversy. Lancet, 2021; 397(10285):1599-601.

Heink S, Yogev N, Garbers C, Herwerth M, Aly L, Gasperi C, Husterer V, Croxford AL, Moller-Hackbarth K, Bartsch HS, Sotlar K, Krebs S, Regen T, Blum H, Hemmer B, Misgeld T, Wunderlich TF, Hidalgo J, Oukka M, Rose-John S, Schmidt-Supprian M, Waisman A, Korn T. Trans-presentation of IL- 6 by dendritic cells is required for the priming of pathogenic $\mathrm{T}_{\mathrm{H}} 17$ cells. Nat Immunol, 2017; 18(1):74-85.

Hermine O, Mariette X, Tharaux PL, Resche-Rigon M, Porcher R, Ravaud P, Bureau S, Dougados M, Tibi A, Azoulay E, Cadranel J. Effect of tocilizumab vs. usual care in adults hospitalized with COVID-19 and moderate or severe pneumonia: a randomized clinical rrial. JAMA Intern Med, 2021; 181(1):32-40.

Horby P, Lim WS, Emberson JR, Mafham M, Bell JL, Linsell L, Staplin N, Brightling C, Ustianowski A, Elmahi E, Prudon B, Green C, Felton T, Chadwick D, Rege K, Fegan C, Chappell LC, Faust SN, Jaki T, Jeffery K, Montgomery A, Rowan K, Juszczak E, Baillie JK, Haynes R, Landray MJ. Dexamethasone in hospitalized patients with Covid-19. N Engl J Med, 2021a; 384(8):693-704.

Horby PW, Pessoa-Amorim G, Peto L, Brightling CE, Sarkar R, Thomas K, Jeebun V, Ashish A, Tully R, Chadwick D, Sharafat M. Tocilizumab in patients admitted to hospital with COVID-19 (RECOVERY): preliminary results of a randomised, controlled, open-label, platform trial. MedRxiv, 2021b; doi:10.1101/2021.02.11.21249258.

Hunter AC, Jones AS. IL-6 as a keystone cytokine in health and disease. Nat Immunol, 2015; 16:448-57.

Iqbal Yatoo M, Hamid Z, Rather I, Nazir QUA, Bhat RA, Ul Haq A, Magray SN, Haq Z, Sah R, Tiwari R, Natesan S, Bilal M, Harapan H, Dhama K. Immunotherapies and immunomodulatory approaches in clinical trials - a mini review. Hum Vaccines Immunother, 2021; 12:1-13.

Izda V, Jeffries MA, Sawalha AH. COVID-19: A review of therapeutic strategies and vaccine candidates. Clin Immunol, 2021; 222:108634.

Jesenak M, Brndiarova M, Urbancikova I, Rennerova Z, Vojtkova J, Bobcakova A, Ostro R, Banovcin P. Immune parameters and COVID-19 infection - associations with clinical severity and disease prognosis. Front Cell Infect Microbiol, 2020; 10:364.

Jones SA, Jenkins BJ. Recent insights into targeting the IL-6 cytokine family in inflammatory diseases and cancer. Nat Rev Immunol, 2018; 18(12):773-89.

Kang S, Tanaka T, Narazaki M, Kishimoto T. Targeting interleukin-6 signaling in clinic. Immunity, 2019; 50(4):1007-23.

Khan FA, Stewart I, Fabbri L, Moss S, Robinson K, Smyth AR, Jenkins G. Systematic review and meta-analysis of anakinra, sarilumab, siltuximab and tocilizumab for COVID-19. Thorax, 2021; - 76(9):907-19.

Kow CS, Hasan SS. Corticosteroid plus tocilizumab in COVID-19: when two is better than one. Chest, 2021a; 159(5):2108-9.

Kow CS, Hasan SS. Interleukin-6 blockade with tocilizumab in COVID-19: does it live up to its hype. Pulmonology, 2021b; 27(1):86-7.

Le RQ, Li L, Yuan W, Shord SS, Nie L, Habtemariam BA, Przepiorka D, Farrell AT, Pazdur R. FDA approval summary: tocilizumab for treatment of chimeric antigen receptor $\mathrm{T}$ cell-induced severe or lifethreatening cytokine release syndrome. Oncologist, 2018; 23:943.

Li P, Lu Z, Li Q, Wang Z, Guo Y, Cai C, Wang S, Liu P, Su X, Huang Y, Dong Y, Qiu W, Ling Y, Yarmus L, Luo F, Zeng L, Bai C, Zhang W. Administration timing and efficacy of tocilizumab in patients with COVID-19 and elevated IL-6. Front Mol Biosci, 2021; 8:651662; doi:10.3389/fmolb.2021.651662.

Malgie J, Schoones JW, Pijls BG. Decreased mortality in coronavirus disease 2019 patients treated with tocilizumab: a rapid systematic review and meta-analysis of observational studies. Clin Infect

\section{Dis, 2020; 50:1007-23.}

Malik YS, Kumar N, Sircar S, Kaushik R, Bhat S, Dhama K, Gupta P, Goyal K, Singh MP, Ghoshal U, El Zowalaty ME, O R V, Yatoo MI, Tiwari R, Pathak M, Patel SK, Sah R, Rodriguez-Morales AJ, Ganesh B, Kumar P, Singh RK. Coronavirus disease pandemic (COVID-19): challenges and a global perspective. Pathogens, 2020; 9(7):519.

Meira F, Albiach L, Carbonell C, Martin-Oterino JA, MartínOrdiales M, Linares L, Macaya I, Aguero D, Ambrosioni J, Bodro M, Cardozo C, Chumbita M, De la Mora M, García-Pouton N, Garcia-Vidal C, Gonzalez-Cordon A, Hernandez-Meneses M, Inciarte A, Laguno M, Leal L, Morata L, Puerta-Alcalde P, Rico V, Letona L, Cozar-Llisto A, Duenas G, Sola M, Torres B, Rojas J, Moreno A, Moreno-Garcia E, Torres M, Martínez JA, Soriano A, Garcia F. Tocilizumab reduces the risk of ICU admission and mortality in patients with SARS-CoV-2 infection. Rev Esp Quimioter, 2021; 13 .

Mombrun M, Valette X. Questioning tocilizumab use in hospitalized patients with coronavirus disease 2019. Chest, 2021; 159(5):2115-6; doi:10.1016/j.chest.2020.11.069.

Moore JB, June $\mathrm{CH}$. Cytokine release syndrome in severe COVID-19. Science, 2020; 368(6490):473-4.

Okoh A, Bishburg E, Grinberg S, Nagarakanti S. Tocilizumab use in COVID-19-associated pneumonia. J Med Virol, 2021; 93:1023-8.

O'Leary K. Tocilizumab for the treatment of severe COVID-19. Nat Med, 2021; doi:10.1038/d41591-021-00031-7.

Pathan NA, Hemingway CA, Alizadeh A, Stephens AC, Boldrick JC, Oragui EE, McCabe C, Welch SB, Whitney A, O'Gara P, Nadel S. Role of interleukin 6 in myocardial dysfunction of meningococcal septic shock. Lancet, 2004; 363:203-9.

Pelaia C, Calabrese C, Garofalo E, Bruni A, Vatrella A, Pelaia G. Therapeutic role of tocilizumab in SARS-CoV-2-induced cytokine storm: rationale and current evidence. Int J Mol Sci, 2021; 22(6):3059.

Peng X, Wang Y, Xi X, Jia Y, Tian J, Yu B, Tian J. Promising therapy for heart failure in patients with severe COVID-19: calming the cytokine storm. Cardiovasc Drugs Ther, 2021; 35:231-47.

Price CC, Altice FL, Shyr Y, Koff A, Pischel L, Goshua G, Azar MM, Mcmanus D, Chen SC, Gleeson SE, Britto CJ, Azmy V, Kaman K, Gaston DC, Davis M, Burrello T, Harris Z, Villanueva MS, Aoun-Barakat L, Kang I, Seropian S, Chupp G, Bucala R, Kaminski N, Lee AI, LoRusso PM, Topal JE, Dela Cruz C, Malinis M. Tocilizumab treatment for cytokine release syndrome in hospitalized COVID-19 patients: survival and clinical outcomes. Chest, 2020; 158(4):1397-408.

Rabaan AA, Al-Ahmed SH, Garout MA, Al-Qaaneh AM, Sule AA, Tirupathi R, Mutair AA, Alhumaid S, Hasan A, Dhawan M, Tiwari R, Sharun K, Mohapatra RK, Mitra S, Emran TB, Bilal M, Singh R, Alyami SA, Moni MA, Dhama K. Diverse immunological factors influencing pathogenesis in patients with COVID-19: a review on viral dissemination, immunotherapeutic options to counter cytokine storm and inflammatory responses. Pathogens, 2021b; 10(5):565.

Rabaan AA, Al-Ahmed SH, Muhammad J, Khan A, Sule AA, Tirupathi R, Mutair AA, Alhumaid S, Al-Omari A, Dhawan M, Tiwari R, Sharun K, Mohapatra RK, Mitra S, Bilal M, Alyami SA, Emran TB, Moni MA, Dhama $\mathrm{K}$. Role of inflammatory cytokines in covid-19 patients: a review on molecular mechanisms, immune functions, immunopathology and immunomodulatory drugs to counter cytokine storm. Vaccines, 2021a; 9(5):436.

Ramaswamy M, Mannam P, Comer R, Sinclair E, McQuaid DB, Schmidt ML. Off-label real world experience using tocilizumab for patients hospitalized with COVID-19 disease in a regional community health system: a case-control study. MedRxiv, 2020; doi:10.1101/2020.0 5.14.20099234

RECOVERY Collaborative Group. Tocilizumab in patients admitted to hospital with COVID-19 (RECOVERY): a randomised, controlled, open-label, platform trial. Lancet, 2021; 397(10285):1637-45.

Rezaei S, Fatemi B, Karimi Majd Z, Minaei H, Peikanpour M, Anjidani N, Taheri A, Dastan F, Mosaed R. Efficacy and safety of tocilizumab in severe and critical COVID-19: a systematic review and meta-analysis. Expert Rev Clin Immunol, 2021; 17(5):499-511. 
Richier Q, Plaçais L, Lacombe K, Hermine O. COVID-19: encore une place pour le tocilizumab? [COVID-19: Still a place for tocilizumab?]. Rev Med Interne, 2021; 42(2):73-8.

Rubin EJ, Longo DL, Baden LR. Interleukin-6 receptor inhibition in Covid-19 - cooling the inflammatory soup. N Engl J Med, 2021; 384(16):1564-5.

Salahshoori I, Mobaraki-Asl N, Seyfaee A, Mirzaei Nasirabad N, Dehghan Z, Faraji M, Ganjkhani M, Babapoor A, Shadmehr SZ, Hamrang A. Overview of COVID-19 disease: virology, epidemiology, prevention diagnosis, treatment, and vaccines. Biologics, 2021; 1(1):2-40.

Sharun K, Tiwari R, Dhama J, Dhama K. Dexamethasone to combat cytokine storm in COVID-19: clinical trials and preliminary evidence. Int J Surg, 2020a; 82:179-81.

Sharun K, Tiwari R, Iqbal Yatoo M, Patel SK, Natesan S, Dhama J, Malik YS, Harapan H, Singh RK, Dhama K. Antibody-based immunotherapeutics and use of convalescent plasma to counter COVID-19: advances and prospects. Expert Opin Biol Ther, 2020b; 20(9):1033-46.

Shimabukuro-Vornhagen, A, Godel P, Subklewe M, Stemmler HJ, Schlober HA, Schlaak M, Kochanek M, Boll B, Von Bergwelt-Baildon MS. Cytokine release syndrome. J Immunother Cancer, 2018; 6:56.

Singh A, Gupta V. SARS-CoV-2 therapeutics: how far do we stand from a remedy? Pharmacol Rep, 2021; 3:1-19.

Sinha P, Linas BP. Combination therapy with tocilizumab and dexamethasone cost-effectively reduces coronavirus disease 2019 mortality. Clin Infect Dis, 2021; doi:10.1093/cid/ciab409.

Stone JH, Frigault MJ, Serling-Boyd NJ, Fernandes AD, Harvey L, Foulkes AS, Horick NK, Healy BC, Shah R, Bensaci AM, Woolley AE, Nikiforow S, Lin N, Sagar M, Schrager H, Huckins DS, Axelrod M, Pincus MD, Fleisher J, Sacks CA, Dougan M, North CM, Halvorsen YD, Thurber TK, Dagher Z, Scherer A, Wallwork RS, Kim AY, Schoenfeld S, Sen P, Neilan TG, Perugino CA, Unizony SH, Collier DS, Matza MA, Yinh JM, Bowman KA, Meyerowitz E, Zafar A, Drobni ZD, Bolster MB, Kohler M, D'Silva KM, Dau J, Lockwood MM, Cubbison C, Weber BN, Mansour MK. BACC bay tocilizumab trial investigators, efficacy of tocilizumab in patients hospitalized with covid-19. N Engl J Med, 2020; 383(24):2333-44.

Tanaka T, Narazaki M, Kishimoto T. Immunotherapeutic implications of IL-6 blockade for cytokine storm. Immunotherapy, 2016; 8:959-70.

Tanaka T, Narazaki M, Kishimoto T. Therapeutic targeting of the interleukin-6 receptor. Annu Rev Pharmacol. Toxicol, 2012; 52:199-219.

Tisoncik JR, Korth MJ, Simmons CP, Farrar J, Martin TR, Katze MG. Into the eye of the cytokine storm. Microbiol Mol Biol Rev, 2012; 76(1):16-32.

Tleyjeh IM, Kashour Z, Riaz M, Hassett L, Veiga VC, Kashour T. Efficacy and safety of tocilizumab in COVID-19 patients: a living systematic review and meta-analysis: first update. Clin Microbiol Infect, $2021 ; 26: 1-13$

Toniati P, Piva S, Cattalini M, Garrafa E, Regola F, Castelli F, Franceschini F, Foca, E, Andreoli L, Latronico N, Research BI. Tocilizumab for the treatment of severe COVID-19 pneumonia with hyperinflammatory syndrome and acute respiratory failure: a single center study of 100 patients in Brescia, Italy. Autoimmun Rev, 2020; 19(7):102568.

Verma AA, Pai M, Saha S, Bean S, Fralick M, Gibson JL, Greenberg RA, Kwan JL, Lapointe-Shaw L, Tang T, Morris AM, Razak F. Managing drug shortages during a pandemic: tocilizumab and COVID-19. CMAJ, 2021; doi:10.1503/cmaj.210531.
Villiger PM, Adler S, Kuchen S, Wermelinger F, Dan D, Fiege V, Butikofer L, Seitz M, Reichenbach S. Tocilizumab for induction and maintenance of remission in giant cell arteritis: a phase 2, randomised, double-blind, placebo-controlled trial. Lancet, 2016; 387:1921-7.

Wang C, Wang Z, Wang G, Lau JY, Zhang K, Li W. COVID-19 in early 2021: current status and looking forward. Signal Transduct Target Ther, 2021; 6(1):114.

Wei XS, Wang XR, Zhang JC, Yang WB, Ma WL, Yang BH, Jiang NC, Gao ZC, Shi HZ, Zhou Q. A cluster of health care workers with COVID-19 pneumonia caused by SARS-CoV-2. J Microbiol Immunol Infect, 2021; 54(1):54-60.

WHO. WHO COVID-19 dashboard - up to date data on pandemic. 2021. Available via https://covid19.who int $/$ ?gclid=CjwKCAiApNSABhAlEiwANuR9YM0k0JigJ56NivXbxLo GNuUC2W0j79EBV9ZLho5WBFDR7AO8Bt2ihoCqfoQAvD BwE (Accessed 28 April 2021).

Xu K, Cai H, Shen Y. Management of corona virus disease-19 (COVID-19): the Zhejiang experience. J Zhejiang Univ Sci B, 2020a; 49:0.

Xu X, Han M, Li T, Sun W, Wang D, Fu B, Zhou Y, Zheng X, Yang Y, Li X, Zhang X, Effective treatment of severe COVID-19 patients with tocilizumab. Proc Natl Acad Sci U S A, 2020b; 117(20):10970-5.

Zhang C, Wu Z, Li JW, Zhao H, Wang GQ. Cytokine release syndrome in severe COVID-19: interleukin-6 receptor antagonist tocilizumab may be the key to reduce mortality. Int J Antimicrob Agents, 2020; 55(5):105954.

Zhao M. Cytokine storm and immunomodulatory therapy in COVID-19: role of chloroquine and anti-IL-6 monoclonal antibodies. Int J Antimicrob Agents, 2020; 55(6):105982.

Zhou F, Yu T, Du R, Fan G, Liu Y, Liu Z, Xiang J, Wang Y, Song B, Gu X, Guan L, Wei Y, Li H, Wu X, Xu J, Tu S, Zhang Y, Chen H, Cao B. Clinical course and risk factors for mortality of adult inpatients with COVID-19 in Wuhan, China: a retrospective cohort study. Lancet, 2020; 395(10229):1054-62.

How to cite this article:

Dhawan M, Dhama K, Parmar M, Sharma A, Angural S. Unravelling the potentialities of tocilizumab for the development of a potential immunotherapeutic regimen against COVID-19- A narrative review. J Appl Pharm Sci, 2021; 11(11):026-033. 